УДК 614.25:378.22:004.738.5.004.14

DOI 10.11603/me.2414-5998.2020.4.11369

Л. Д. Танцюра

ORCID https://orcid.org/0000-0002-8294-4122

ResearcherID AAH-4925-2019

I. В. Кисельова

ORCID https://orcid.org/0000-0002-9083-8223

ResearcherID AAH-3914-2019

Scopus Author ID 57193986489

А. В. Біляєв

ORCID https://orcid.org/0000-0003-3913-2900

Scopus Author ID 6507408057

Національна медична академія післядипломної освіти імені П. Л. Шупика, Київ

\title{
АУДИТ ОЦІНКИ ЛІКАРЯМИ ДИСТАНЦІЙНОЇ ФОРМИ НАВЧАННЯ НА ЕТАПІ ПІСЛЯДИПЛОМНОЇ ОСВІТИ
}

\author{
L. D. Tantsiura, I. V. Kyselova, A. V. Biliaiev \\ P. Shupyk National Medical Academy of Postgraduate Education, Kyiv

\section{AUDIT OF DOCTOR'S EVALUATION OF DISTANCE LEARNING AT THE POSTGRADUATE EDUCATION STAGE}

\begin{abstract}
Анотація. На прикладі опитування лікарів-інтернів, слухачів циклів спеціалізації та тематичного удосконалення проведено аналіз ефективності дистанційної форми навчання кафедри дитячої анестезіології та інтенсивної терапії Національної медичної академії післядипломної освіти імені П. Л. Шупика. Показана затребуваність лікарів онлайн-формату для отримання теоретичних знань і неприйнятність дистанційної форми навчання в разі необхідності набуття або вдосконалення практичних/мануальних навичок. Виходячи з отриманих результатів опитування, наводяться позитивні і негативні сторони дистанційного навчання. Лікарі-інтерни й слухачі кафедри циклів спеціалізації та тематичного удосконалення віддали перевагу комбінованій моделі, тобто поєднанню очного і дистанційного видів навчання.
\end{abstract}

Ключові слова: дистанційне навчання лікарів-інтернів; дистанційний формат навчання лікарів; післядипломна освіта.

Abstract. During the quarantine, everyone was forced to start distance teaching and learning. This form of education has its advantages and disadvantages. A survey of interns and doctors who studied at the Department of Pediatric Anesthesiology and Intensive Care of P. Shupyk National Medical Academy of Postgraduate Education was carried out. Based on the results of the survey, the positive and negative aspects of distance learning are presented. Interns and doctors preferred the distance format to get theoretical knowledge. However, to obtain practical/manual skills, offline format is required. Interns and students of the department of cycles of specialty and thematic improvement gave preference to the combined model, i.e. a combination of full-time and distance learning.

Key words: distance learning for interns; online training for doctors; postgraduate education.

Вступ. Дистанційні способи комунікації активно увійшли в усі сфери життя, в тому числі і сферу освіти. Отримувати та ділитись інформацією онлайн стає все більш затребуваним у світі. Однією 3 найактуальніших переваг такого формату отримання знань $\epsilon$ можливість навчатися незалежно від місця перебування, без витрат на організацію

( ) Л. Д. Танцюра, І. В. Кисельова, А. В. Біляєв трансферу та проживання, з можливістю паралельно продовжувати традиційний спосіб життя.

Умови карантину, в яких раптом опинилася вся країна у зв'язку з пандемією COVID-19, зробили виклик системі освіти. Було необхідним у короткі строки організувати перехід навчання в онлайнформат, змінити підходи у викладанні, налагодити комунікацію зі слухачами. Раніше дистанційні форми навчання поступово входили в арсенал спо- 
собів донесення інформації та використовувалися для підвищення кваліфікації лікарів. Проте раптова зміна формату навчання з повним переходом в онлайн-режим викладання поставила виклик перед багатьма кафедрами та викладачами.

Від початку постали питання з ресурсами як у викладачів, так і в тих, хто навчався. 3 одного боку, це технічні ресурси: доступ до високошвидкісного Інтернету, пошук програмного забезпечення та платформ, які б дозволяли проводити онлайн-навчання в оптимальному форматі, з іншого - людський ресурс: різка зміна умов й оперативне впровадження нових технологій потребували від викладачів набуття нових навичок і компетенцій, корекції методів викладання та контролю знань зі збереженням якості інформації. Не всі учасники освітнього процесу виявилися готовими до нових умов роботи. Це було пов'язано не тільки з відсутністю технічних можливостей і якісного зв'язку. Дистанційне навчання потребує самодисципліни, мотивації, відповідальності, структурованого підходу та вельми великого обсягу самостійної роботи.

Мета статті - проаналізувати ефективність і недоліки дистанційної форми навчання на прикладі опитування лікарів-інтернів, слухачів циклів спеціалізації та тематичного удосконалення кафедри дитячої анестезіології та інтенсивної терапії Національної медичної академії післядипломної освіти імені П. Л. Шупика. На підставі результатів опитування запропонувати оптимальний формат навчання, який би задовольнив потреби лікарів на етапі післядипломної підготовки.

Теоретична частина. За період карантину на кафедрі дитячої анестезіології та інтенсивної терапії пройшли потоки слухачів, які повинні були отримати знання й оволодіти навичками для засвоєння нової спеціальності (лікарі-інтерни другого року навчання та слухачі циклу спеціалізації), а також лікарі, які вже працюють за спеціальністю та прийшли підвищити кваліфікацію на цикл тематичного удосконалення (ТУ). Перехід на повну дистанційну форму навчання з використанням інтернет-мережі й онлайн-технологій був вимушеним кроком, пов'язаним із необхідністю продовжувати навчання в умовах ізоляції під час пандемії.

Існують два підходи до проведення занять онлайн - синхронне та асинхронне. Під час синхронного навчання події відбуваються в режимі реального часу. Викладач і слухачі знаходяться в онлайнрежимі в той же самий час. При асинхронному навчанні слухачі отримують освітній контент у за- пису, тобто викладачу не обов'язково знаходитись он-лайн разом із слухачами, матеріал попередньо підготовлюють та викладають на серверних платформах або в інтернет-ресурсах [2]. На кафедрі обрали синхронний варіант проведення занять, з тим, щоб була можливість для слухачів спілкування 3 викладачем, а для викладачів - зворотного зв'язку зі слухачами у режимі реального часу. Такий варіант надає змогу не тільки передавати інформацію, але й залучати аудиторію до дискусії.

Здобувши певний досвід, співробітники кафедри намагалися з'ясувати, наскільки онлайн-форма навчання була ефективною і задовольняла слухачів як вимушена альтернатива очній формі навчання. 3 цією метою наприкінці циклів інтернатури, спеціалізації та тематичного удосконалення було проведене анонімне опитування серед слухачів. Окремо опитували лікарів, які освоювали навички нової професії (інтерни та група спеціалізації), та вже досвідчених лікарів, які проходили тематичне удосконалення. Опитування проводилося на платформі «SurveyMonkey» та складалося з 10 питань, які враховували специфіку навчання в кожній групі, але деякі питання були ідентичними для обох груп.

Так, на питання «Чи доцільний, на Ваш погляд, дистанційний формат навчання на тому циклі, на якому Ви навчались?» у групі лікарів-інтернів та спеціалізації ствердно відповіли 50 \% опитуваних, а в групі лікарів циклу ТУ - 82 \% (рис. 1). Це свідчить про те, що онлайн-навчання $є$ прийнятним для підвищення кваліфікації, але неприпустиме для опанування нової спеціальності, зокрема такої, як «Дитяча анестезіологія», яка передбачає необхідність набуття певного набору важливих мануальних навичок, що, в принципі, неможливо при дистанційній формі навчання.

Це підтверджувалося відповідями на запитання «Які з перерахованих критеріїв дистанційного навчання, на Вашу думку, є найактуальнішими?» Більшість слухачів в обох групах найбільш важливими перевагами відмітили «економію часу та фінансових витрат», «можливість отримання інформації незалежно від відстані», «можливість навчатись і продовжувати працювати».

А на запитання «Які з перерахованих критеріїв дистанційного навчання, на Вашу думку, є найбільш негативними?» $90 \%$ опитуваних у групі лікарів-інтернів та спеціалізації і 60 \% в групі лікарів циклу ТУ вказали на неможливість оволодіння практичними навичками. Цей тезис є особливо актуальним, коли передбачається не тільки отримання 


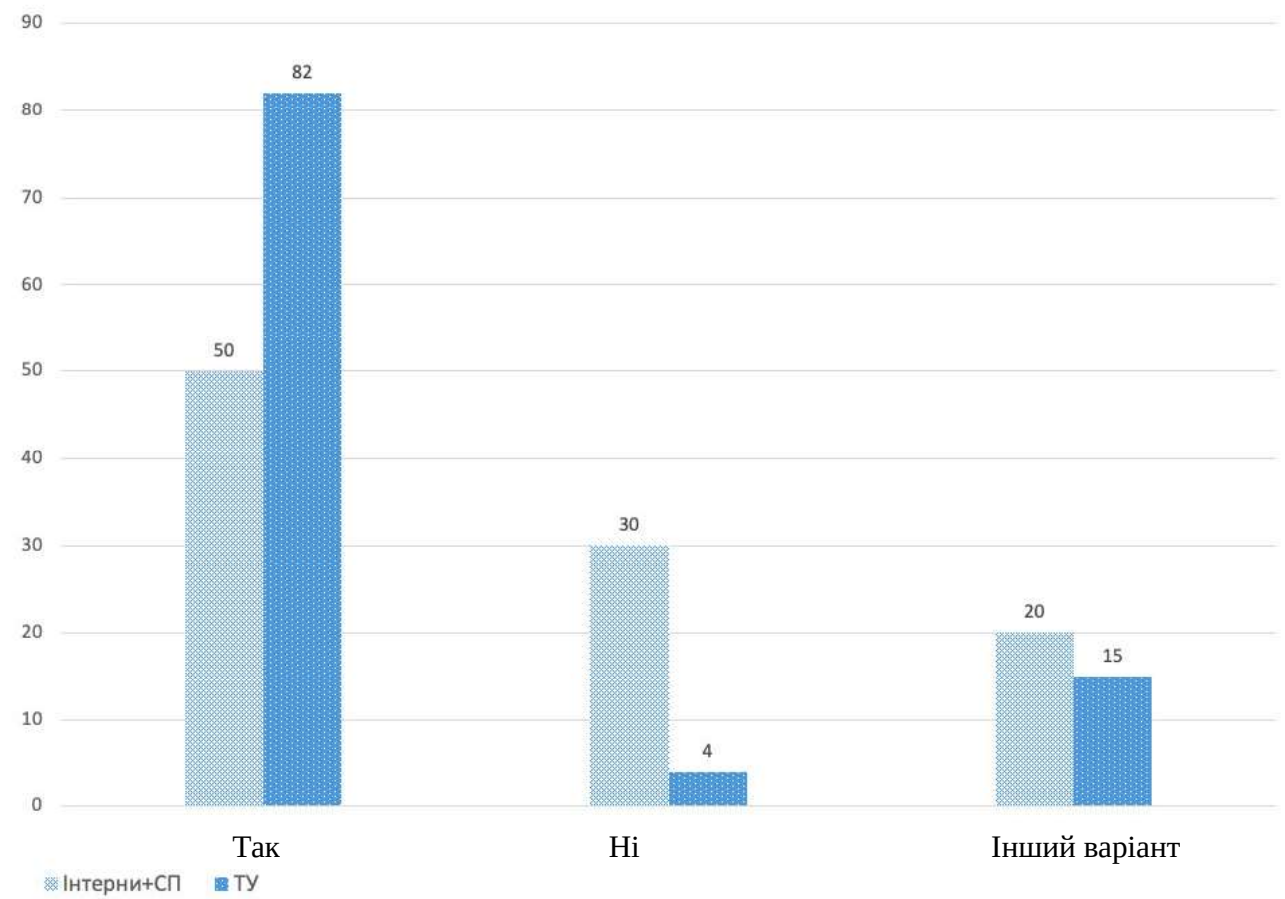

Рис. 1. Питання: «Чи доцільний, на Ваш погляд, дистанційний формат навчання на тому циклі, на якому Ви навчались?»

нових знань, а й набуття або вдосконалення певних навичок, у тому числі й мануальних. Додатково як негативні критерії дистанційної форми навчання слухачі обох груп відмітили такі пункти: «бракує живого спілкування з викладачем» та «недостатне спілкування з колегами». Відмітили технічні труднощі $47 \%$ опитуваних у групі інтернів і спеціалізації та 33 \% в групі циклу ТУ (рис. 2).

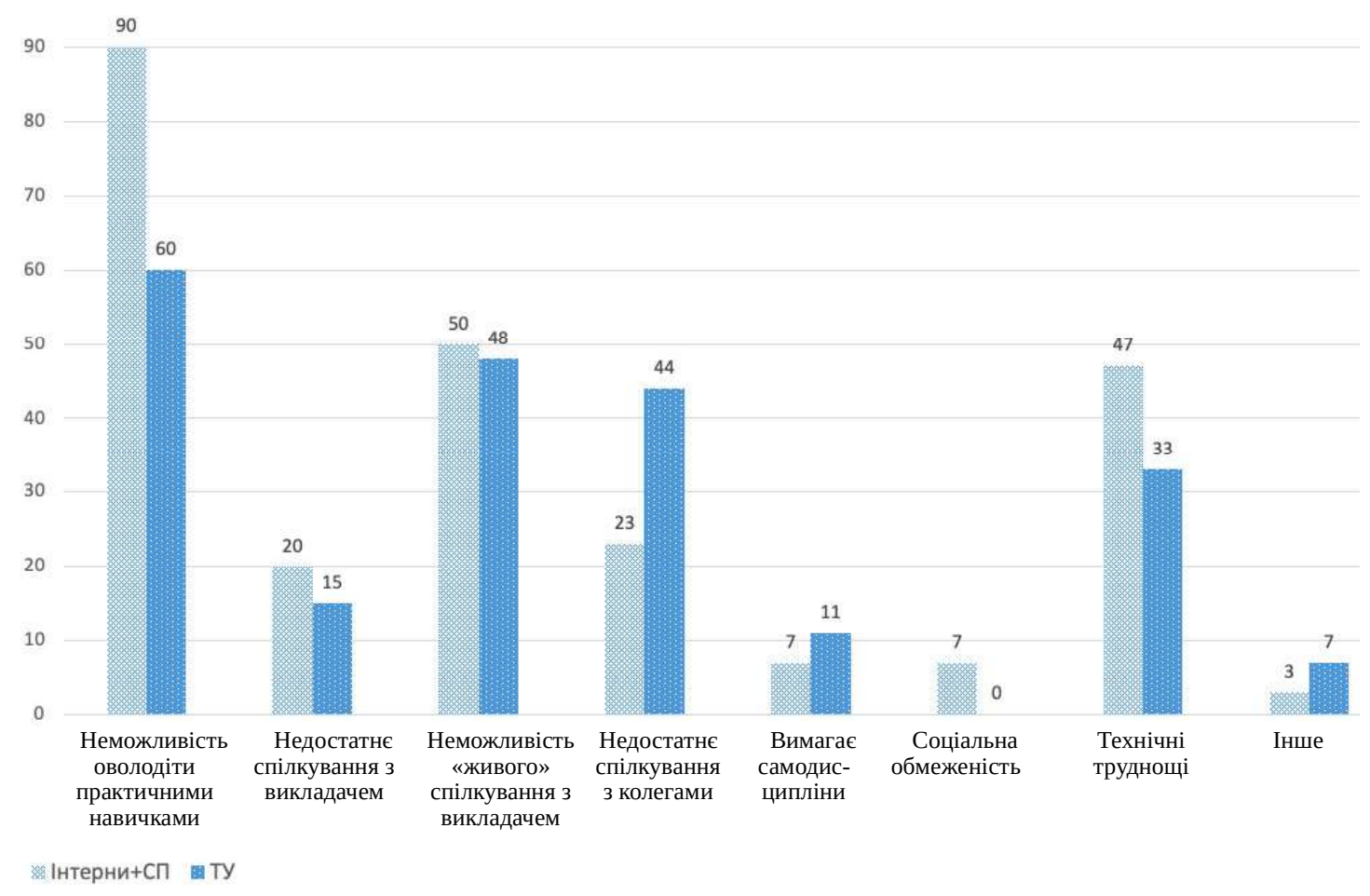

Рис. 2. Питання: «Які з перерахованих критеріїв дистанційного навчання, на Вашу думку, $€$ найбільш негативними?» 
Слід окремо зупинитися на засвоєнні практичних навичок і зазначити, що виділяють як технічні/мануальні навички, так і нетехнічні. До останніх належать здатність прийняття рішень, усвідомлення клінічної ситуації, вміння працювати в команді, навички комунікації як із пацієнтами, так і з колегами - в реаліях сучасної медичної освіти всім цим можна оволодіти лише при очній формі навчання: біля ліжка пацієнта на клінічних базах або з використанням симуляційних сценаріїв [1]. Стосовно оволодіння мануальними (технічними) навичками автори вважають, що велику роль у процесі відіграє присутність вчителя, наставника або досвідченого колеги, який in situ дає зворотний зв'язок на предмет коректності виконання тієї чи іншої техніки. Отже, той факт, що слухачі в опитуванні відмітили неможливість оволодіти мануальними навичками та брак спілкування з викладачем і колегами, як негативні критерії, на нашу думку, з'являється цілком логічним.

Але на запитання «Чи відрізняється для Вас засвоєння/отримання інформації при очній та дистанційній формах навчання?» думки груп поділилися. Так, у групі лікарів-інтернів і слухачів групи спеціалізації 63 \% опитуваних відмітили очний формат зручнішим, і лише 3 \% віддали перевагу дистанційній формі. В той час як у групі підвищення кваліфікації на зручність очного формату вказали лише 30 \% лікарів, 41 \% вважали, що форма навчання не впливає на засвоєння матеріалу, а дистанційну форму як найбільш зручну обрали 11 \% респондентів (рис. 3). Ці дані підтверджують, що для засвоєння нових знань та навичок необхідний очний формат навчання.

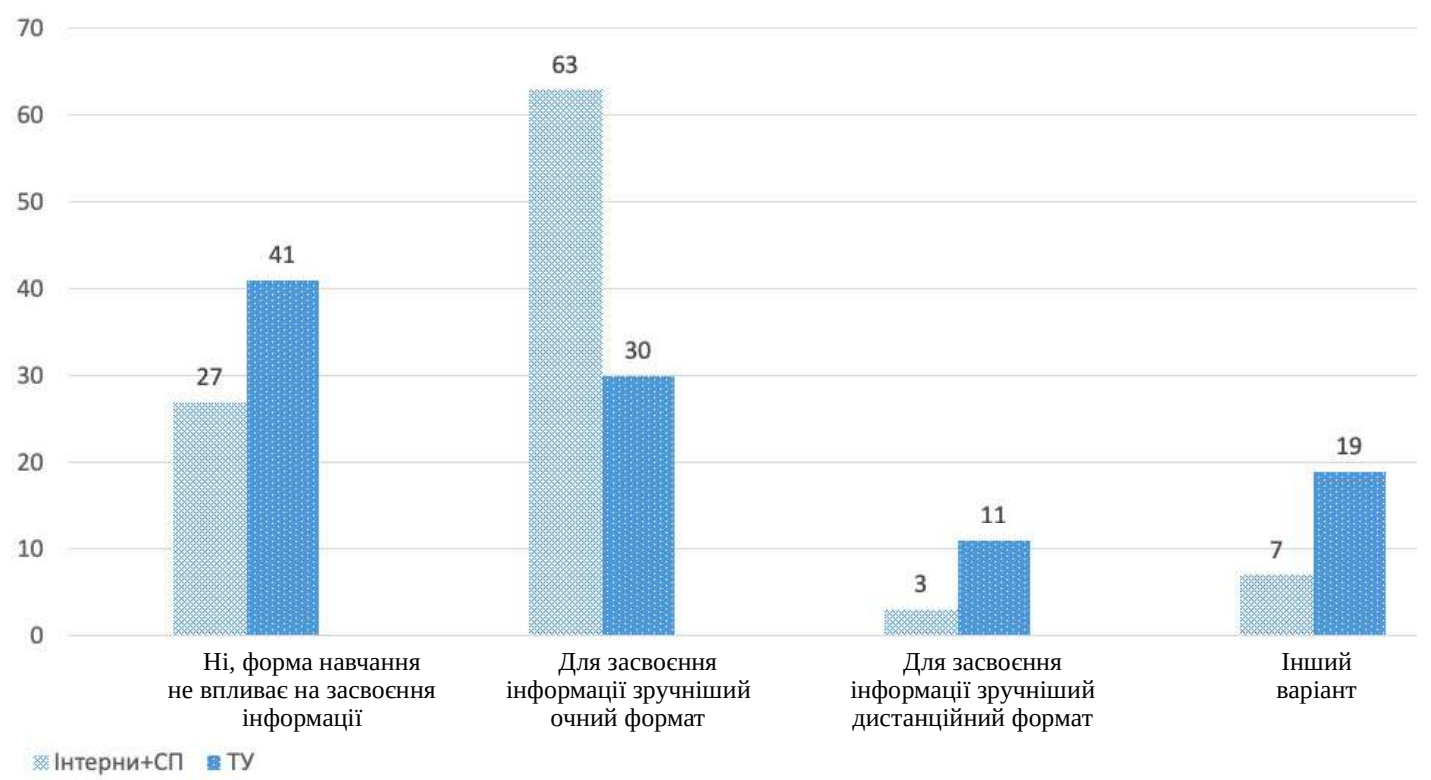

Рис. 3. Питання: «Чи відрізняється для Вас засвоєння/отримання інформації при очній та дистанційній формах навчання?»

I на запитання «Якому формату навчання Ви віддали би перевагу?» більшість респондентів в обох групах (63 \% серед інтернів та спеціалізації; 56 \% серед лікарів циклу ТУ) обрали очно-дистанційну форму (рис. 4). Ймовірно, в мінливих умовах сучасності комбінація цих форм є логічною для більшості видів навчання. Надання інформації, обговорення питань та обмін думками припустимо проводити в онлайн-режимі. Тоді як набуття практичних навичок - технічних і нетехнічних - потребує переважно очного формату. Залежно від потреб слухачів відсоткове співвідношення очної та дистанційної форм може змінюватись.
Висновки та перспективи подальших досліджень. Проведене опитування продемонструвало думку лікарів щодо позитивних та негативних сторін дистанційного навчання. 3 точки зору опитуваних, дистанційний формат навчання надає можливість отримати нову інформацію, ознайомитись із сучасними технологіями діагностики і терапії, обговорити наболілі та важливі питання. Але в такому форматі оволодіти практичними навичками, перш за все мануальними, стає складним завданням. На думку опитуваних слухачів та інтернів, оптимальною формою може бути очнодистанційна форма навчання. Але перспективи i 


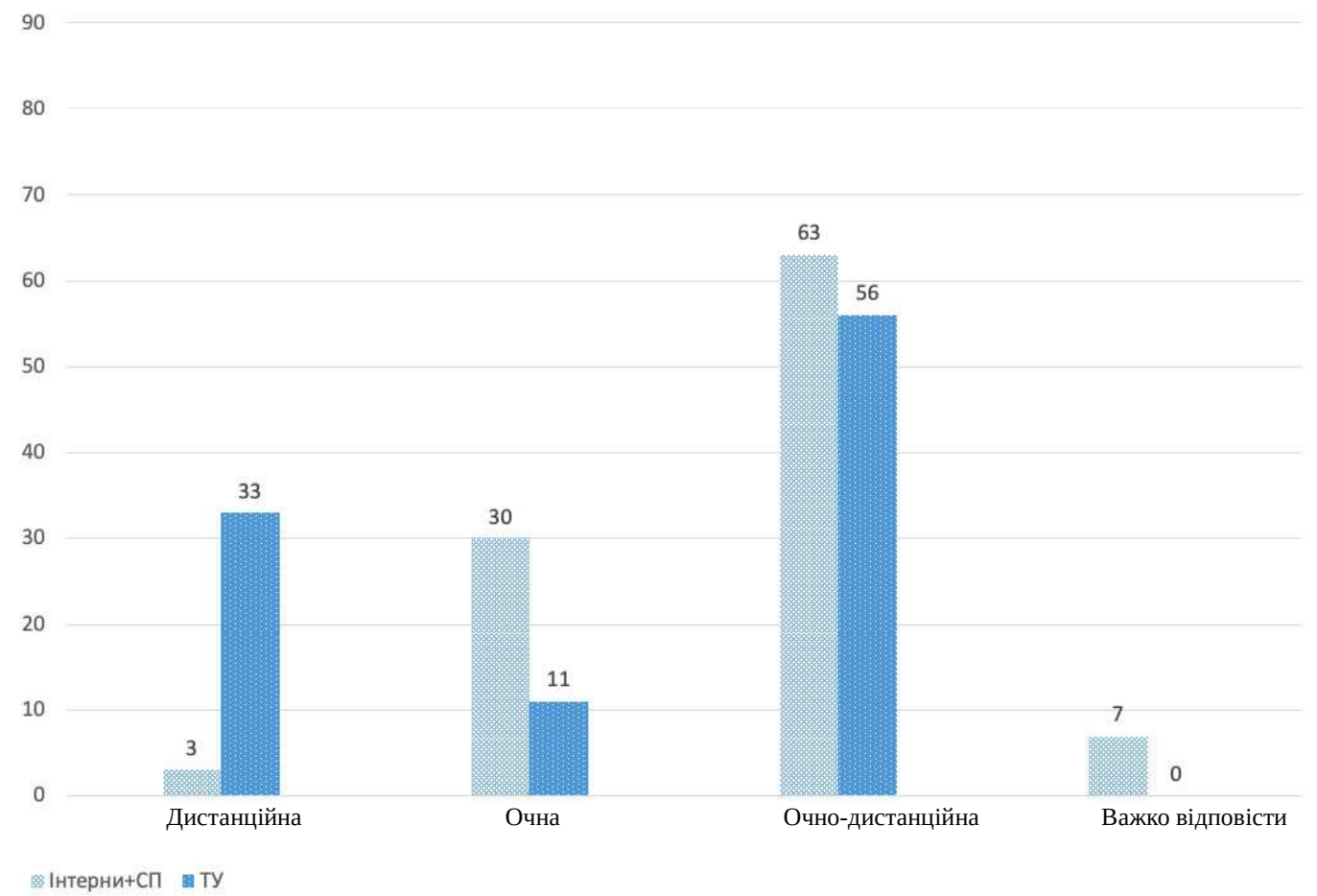

Рис. 4. Питання: «Якому формату навчання Ви віддали би перевагу?»

прийнятність дистанційного навчання саме в медичній освіті потребують подальшої деталізації та вивчення спеціалістами, які займаються вдосконаленням освіти.

\section{Список літератури}

1. Flin R. Non-technical skills: identifying, training, and assessing safe behaviours. In Manual of Simulation in Healthcare / R. Flin, N. Maran. - Oxford : Oxford University Press, 2015. - P. 564.

\section{References}

1. Flin, R., \& Maran, N. (2015). Non-technical skills: identifying, training, and assessing safe behaviours. In Manual of Simulation in Healthcare. Oxford, UK: Oxford University Press.

2. Ko S. Teaching online. A practical guide / S. Ko, S. Rossen. - New York : Routledge (4th ed), 2017. - P. 510. A practical guide. (4th ed.). New York: Routledge.

Отримано 02.09.20 Рекомендовано 08.09.20

Електронна адреса для листування: nicu72.anesth@gmail.com 